University of Windsor

Scholarship at UWindsor

2014

\title{
Organizational ingenuity and the paradox of embedded agency: The case of the embryonic Ontario solar energy industry
}

Kent Walker Dr.

Odette School of Business

Francine Schlosser Dr.

Odette School of Business

David Deephouse Dr.

University of Alberta

Follow this and additional works at: https://scholar.uwindsor.ca/odettepub

Part of the Business Administration, Management, and Operations Commons, and the Entrepreneurial and Small Business Operations Commons

\section{Recommended Citation}

Walker, Kent Dr.; Schlosser, Francine Dr.; and Deephouse, David Dr.. (2014). Organizational ingenuity and the paradox of embedded agency: The case of the embryonic Ontario solar energy industry. Organization Studies.

https://scholar.uwindsor.ca/odettepub/76

This Article is brought to you for free and open access by the Odette School of Business at Scholarship at UWindsor. It has been accepted for inclusion in Odette School of Business Publications by an authorized administrator of Scholarship at UWindsor. For more information, please contact scholarship@uwindsor.ca. 


\section{Organizational ingenuity and the paradox of embedded agency: The case of the embryonic Ontario solar energy industry}

We examine organizational ingenuity within the paradox of embedded agency where organizational stakeholders are constrained in their behaviors by institutions, yet also influence and change these institutions. In this study organizational ingenuity represents the agency component and institutional constraints the embedded component. We build theory about ingenuity from a four-year case study of the embryonic Ontario solar industry. There were two major institutional constraints, limited grid access and political uncertainty. These led to four ingenuity strategies that emerged at different times and levels of analysis that challenged, complied with, or escaped the constraints. We combine these findings to develop a process model of the emergence of ingenuity in this embryonic industry. Lastly, we find that extending legitimacy to an ingenuity strategy is necessary for its success.

\section{Keywords}

Ingenuity, institutional theory, institutional constraints, legitimacy, paradox of embedded agency, solar energy industry 


\section{Introduction}

Organizational ingenuity is an emerging construct in management research that encompasses innovative activity within institutional constraints (Lampel, Honig, \& Drori, 2011). As an emerging construct, it requires both theoretical analysis and qualitative research to refine its definition, formulate propositions, and examine its empirical applicability (Kaplan, 1964; Suddaby, 2010a). Since ingenuity takes place within institutional constraints (Lampel et al., 2011), we draw from institutional theory to orient our research (Suddaby, 2006).

We connect ingenuity to two related puzzles in institutional theory concerning how stakeholders interact with the institutional environment. One puzzle involves the tension between top-down and bottom-up processes in the creation, maintenance, and change of institutions (Scott, 1994, 2008). The second puzzle is the paradox of embedded agency, which considers how institutional change is possible, given that stakeholders are constrained by the very institutions they seek to change (Garud, Hardy \& Maguire, 2007; Seo \& Creed, 2002; Zietsma \& Lawrence, 2010). In both puzzles, existing institutional constraints place top-down pressure on stakeholders to conform, a process known as institutional isomorphism (DiMaggio \& Powell, 1983), whereas stakeholders often seek to change these constraints from the bottom-up. Although organizing to change institutions is a component of institutional entrepreneurship (DiMaggio, 1988; Dorado, 2005, Perkmann \& Spicer, 2007), ingenuity is unique because it also includes entrepreneurial innovation within structural constraints (Lampel et al., 2011), and these innovations and the organizations creating them must have legitimacy from the institutional environment (Van de Ven \& Garud, 1989). There has been little empirical attention to how stakeholders in embryonic industries use bottom-up processes when facing powerful institutional constraints (Van Dijk, Berends, Jelinek, Roome \& Weggeman, 2011; Scott, 2008; Suddaby, 2010b). Accordingly, we 
address the following research question: How does organizational ingenuity play a role in the paradox of embedded agency within an embryonic industry?

We answer our research question using a longitudinal case study of the embryonic solar energy industry in Ontario during 2009-12 with data from interviews of 22 industry stakeholders and 91 media articles. We use these data to identify our three main constructs of interest, organizational ingenuity, institutional constraints, and legitimacy, and we develop a process model that tracks their evolution over time.

Our study addresses a number of central topics regarding ingenuity and its linkages to institutional theory. First, we find that Oliver's (1991) set of responses to institutional processes is a useful way to conceptualize types of ingenuity strategies and thus contribute to the construct clarity and underlying nature of ingenuity (Suddaby, 2010a). In so doing, we show that these ingenuity strategies are linked to business innovation and entrepreneurial action and occur at different levels of analysis (Lampel et al., 2011). Second, we identify a condition for the development of ingenuity (Lampel et al., 2011), specifically when successful innovation ironically engenders institutional constraints. Third, we examine the dynamics of organizational ingenuity (Lampel et al., 2011) by showing how ingenuity strategies and their legitimacy evolve over time. In so doing, we contribute to the understanding of dynamic behavior of entrepreneurs facing top-down institutional forces (Barley \& Tolbert, 1997; Greenwood et al., 2002; Perkmann \& Spicer, 2007; Scott, 2008; Suddaby, 2010b).

We proceed as follows. First, we review the literature on ingenuity and the paradox of embedded agency; this sets the theoretical context for our case study (Strauss \& Corbin 1998; Suddaby 2006). Second, we discuss our methodology, including our research context, the data, and the analyses. Third, we present our findings organized around the induced process model of 
ingenuity. Fourth, we discuss the implications for researchers, policy-makers, and managers, followed by a brief conclusion.

\section{Theoretical Foundations}

Ingenuity

There is little research conceptualizing ingenuity. We adopt the definition presented by the editors for this special issue titled Discovering Creativity in Necessity: Organizational Ingenuity under Institutional Constraints: Ingenuity is "the ability to create innovative solutions within structural constraints using limited resources and imaginative problem solving" (Lampel et al., 2011 , p. 458). Ingenuity takes place within institutional constraints, and it involves adapting to existing constraints, developing new domains of action, and/or changing the constraints (Lampel et al. 2011). Ingenuity is closely aligned yet different from creativity, innovation and agility. We define each in turn then differentiate them from ingenuity.

Creativity is defined as "the production of novel and useful ideas in any domain" and innovation as the "successful implementation of creative ideas within an organization" (Amabile et al., 1996, p. 1155). What sets innovation apart from creativity is its implementation within organizations. Creativity can thus be viewed as a first step to innovation. Innovative ideas need not be new to the world but must perceived as new to the people and can include new products, processes, markets, supplies, and organizations (Rogers, 1983; Schumpeter, 1986; Van de Ven, 1986). Ingenuity is "the ability to create innovative solutions" and it incorporates not only producing novel, useful ideas but also implementing them. Therefore, creativity and innovation are necessary - but not sufficient - parts of ingenuity. The final parts of ingenuity are the 
presence of structural constraints and stakeholders with limited resources innovating within these constraints.

Agility is defined as “a firm's ability to cope with rapid relentless and uncertain changes and thrive in a competitive environment of continually and unpredictably changing opportunities" (Lu \& Ramamurthy, 2011, p. 932). Researchers predominantly in management of technology (e.g., Sambamurthy, Bharadwaj \& Grover, 2003) and strategy (e.g., Goldman, Nagel \& Preiss, 1995; Roth, 1996; Sull, 2010) have been preoccupied with strategic agility because this concept deals with firm success. Ingenuity bears some resemblance to strategic agility primarily through its focus on ability. Agility focuses less on particular ideas and more on adapting to a changing, uncertain, and competitive environment. In contrast, ingenuity focuses more on ideas implemented in the context of a constraining institutional environment, which may or may not be changing (Lampel et al. 2011).

The paradox of embedded agency in institutional theory

Institutional theorists have demonstrated how, when constrained by institutional forces, organizations tend to become similar over time (DiMaggio \& Powell, 1983; Heugens \& Lander, 2009; Tolbert \& Zucker, 1996). We define institutional constraints as limitations or restrictions on the behavior of stakeholders (Seo \& Creed, 2002; Scott 2008). Initial research focused on how stakeholders are relatively passive recipients of constraints (DiMaggio \& Powell, 1983; Mezias, 1990). In subsequent research, stakeholders were conceived as actively pursuing interests and thus had varying responses to institutional pressures (DiMaggio, 1988; Lawrence \& Suddaby, 2006; Oliver, 1991; Perkmann \& Spicer, 2007; Scully \& Meyerson, 1996; Zietsma \& Lawrence, 2010). Seo and Creed (2002) theorized that potential change agents would mobilize and exhibit collective action to change institutions. 
These two areas of investigation have been labeled the paradox of embedded agency where stakeholders are constrained in their behaviors by institutions, yet they also influence and change institutions (Garud et al., 2007; Seo \& Creed, 2002). The paradox of embedded agency is a theoretical framework that incorporates both top-down and bottom-up institutional development. Given that ingenuity takes place within institutional constraints (Lampel et al., 2011), we propose that ingenuity is important to the bottom-up efforts of stakeholders in the paradox of embedded agency.

Although no research to date has examined the role of ingenuity in the paradox of embedded agency, research examining institutional entrepreneurship provides some insights. Institutional entrepreneurship is the examination of industry stakeholders as drivers of institutional change (DiMaggio 1988; Dorado 2005; Garud, Jain \& Kumaraswamy 2002; Rao 1998). As Perkmann and Spicer (2007) point out, research in institutional entrepreneurship has found that stakeholders can drive change through the formation of collaborations (DiMaggio 1988; Dorado 2005), through the identification of cause and effect relationships (Greenwood et al., 2002; Strang \& Meyer 1993), and the importance of legitimizing change (Creed, Scully \& Austin, 2002; Lounsbury, Ventresca \& Hirsch, 2003; Rao 1998).

Not only is legitimizing change important, maintaining legitimacy is also a central concern for stakeholders who face institutional constraints (Ashforth \& Gibbs, 1990; Greenwood et al., 2002; Suchman, 1995). We define legitimacy as the generalized acceptability of an entity or practice within a social system (Deephouse \& Suchman, 2008; Suchman, 1995). Legitimacy is important because it enables an entity to obtain necessary resources, reduce uncertainty, and ultimately enhance survivability (Aldrich \& Fiol, 1994; DiMaggio \& Powell, 1983; Drori \& 
Honig, 2013; Suchman, 1995). Because ingenuity occurs within institutional constraints, it is important to consider the legitimacy of ingenious stakeholders and their actions.

We examine four types of legitimacy in our study: pragmatic, moral, cognitive, and regulative. Suchman (1995) divided legitimacy into three categories: pragmatic, moral and cognitive. Pragmatic legitimacy addresses the question: what's in it for me? Its assessment is based on self-interest. Moral legitimacy addresses the question: what's in it for society? Its assessment is based on normative approval and the promotion of social welfare. Cognitive legitimacy is described as passive acceptance and the absence of questions (Meyer \& Scott, 1983; Suchman, 1995). Scott (1994) also divided legitimacy into three categories: regulative, normative, and cognitive. For our purposes, his conceptualizations of normative and cognitive types are sufficiently similar to the moral and cognitive dimensions of Suchman (1995). The addition of regulative legitimacy represents acceptability to the rules and procedures of authoritative bodies, most commonly the state. As such, regulative legitimacy is indicative of a top-down institutional constraint.

\section{Method}

Qualitative methodology

There is limited research on the subject of organizational ingenuity, and our research question asks: How does organizational ingenuity play a role in the paradox of embedded agency within an embryonic industry? Given this, we used a qualitative case study methodology because it is appropriate when examining "how" and "why" questions in a novel setting that facilitate building new theory (Eisenhardt, 1989; Eisenhardt \& Graebner, 2007; Yin, 2009). Our case is the 
embryonic Ontario solar energy industry, a part of the broader energy industry. We used interviews and an analysis of media reports to address our research question.

We first describe our research context. We then explain how we collected and analyzed our interview and media data. We conclude this section by discussing how we developed our process model of ingenuity strategies emerging over time in response to institutional constraints.

\section{Research context}

We examined the embryonic solar energy industry in Ontario from January 2009 to July 2012. This setting was appropriate for answering our research question because the industry essentially began in 2009 when the Ontario government passed the Green Energy Act (GEA) and we observed ingenuity within embedded agency. Our case is consistent with Eisenhardt and Graebner's (2007) recommendation to select cases that are particularly suited to investigating constructs of interest and the relationships among them.

With a population of 17 million people, Ontario is the most populous province in Canada. The province is plagued with increasing energy demands and limited nonrenewable resources and, therefore, arguably stands to gain the most from investment in renewable sources of energy. Consequently, the province proceeded aggressively with an agenda to promote investment in renewable energy (solar, wind and biomass). In February 2009, the Liberal government of Ontario passed the GEA that permitted renewable energy to contribute up to seven percent of the province's energy needs. The GEA was created to spur investment in renewable energy, encourage energy conservation, and create jobs. A key component of the GEA is the Feed-inTariff (FIT) program, which is the first comprehensive FIT program in North America (Ontario Ministry of Energy, 2012). The program allows homeowners, organizations, and private developers to generate renewable energy and sell it at guaranteed rates for a fixed term to the 
Ontario Power Authority (OPA), a crown corporation responsible for the entire electricity system of the province. The heart of the solar energy industry is in southwestern Ontario. At latitude 42.2 $2^{\circ}$ North, Essex County is the southernmost tip of Canada and receives the most powerful sunlight in the country. The city of Windsor in Essex County is the leading regional city and home to many of the solar energy entrepreneurs.

\section{Interviews}

We conducted two waves of interviews. The first was in June-July 2011. At this point in time, the fate of the GEA was an important issue in the fall provincial election, which created considerable political uncertainty (described below). The second wave of interviews was in JuneJuly 2012, after the Liberal government was re-elected and made some changes to the GEA. This allowed us to learn more about the evolution of the initial ingenuity strategies and the development of new ingenuity strategies in response to the few changes in government policy.

Our initial sample of participants was selected based upon our knowledge of the industry gleaned through media coverage of influential Ontario solar industry stakeholders. From this sample, we used the snowball technique. We conducted 12 interviews in summer 2011. All 12 participants were asked for a follow-up interview in June 2012. One had left the industry after his firm went bankrupt; six were not available; and five spoke to us again. We also interviewed 10 more people identified through the snowball technique. Our sample contained participants from various stakeholder groups and was reflective of the population because it included most of the main players in the regional solar cluster. Participants were either the highest ranked individual at the organization or the highest ranked individual within the Canadian operation of a multinational company. Table 1 provides general, non-identifying information on our participants, including the organization they worked for, their position within the organization, 
and when they were interviewed. Interviewing various stakeholders with diverse and sometimes conflicting perspectives reduced the likelihood of convergent sense-making and impression management and thus gave us a comprehensive understanding of the industry (Eisenhardt \& Graebner, 2007). Furthermore, interviewing diverse stakeholders helped offset biases or lapses (Eisenhardt \& Graebner, 2007; Van Dijk et al., 2011). Lastly, through our media analysis we ascertained that most of the major players in the regional solar energy industry were interviewed.

Insert Table 1 about here

Our interviews were conducted as follows. We asked semi-structured questions centered on the nature of the person and the organization he or she worked for, the institutional constraints, and the responses to these constraints. The interviews ranged from just under one hour to nearly two hours. All interviews were recorded and transcribed.

Two of the authors and a research assistant subsequently analyzed the interviews using NVIVO 9. We coded the data according to conceptualizations of institutional constraints and ingenuity. Our analysis included topic intensity and topic commonality among the participants. Institutional constraints were coded in terms of political, environmental, social, and technological categories. These were general barriers faced by the solar industry that were external and difficult to control. We coded ingenuity as any creative and useful idea that was innovatively implemented while operating under institutional constraints. Specifically, any new strategy that had yet to appear in the Ontario solar industry that was developed in response to the identified institutional constraints was coded as organizational ingenuity. Coding ingenuity in this way permitted us to examine the successes (i.e., the strategy resulted in either a change to the 
constraints or enabled stakeholders to escape them) and failures (i.e., the strategy neither changed the constraints nor helped stakeholders escape them). This is in contrast to identifying ingenuity after constraints had been modified or avoided, which would have limited our analysis to successful strategies only. Our longitudinal analysis of the Ontario solar industry from its birth to its current state enabled us to determine if a strategy was novel and innovative. In addition, it enabled us to determine if the strategy was successful within the time period examined. We resolved discrepancies through discussion (Margolis \& Molinsky, 2008).

\section{Media articles}

We conducted a content analysis of all articles about solar energy in The Windsor Star, the largest daily newspaper in southwestern Ontario. Reading these articles enhanced our understanding of the industry. Our content analysis allowed us to further examine the evolution of the institutional constraints, organizational ingenuity, and legitimacy over the study period and to triangulate with our interview findings. Following Bansal and Clelland (2004), a single source of media data was used to avoid duplicate news.

In 2009 and 2010, The Windsor Star published only four articles about the solar industry. However, from January 2011 to July 2012, it published 87 articles, for a total sample of 91. This demonstrated the rapid and growing importance of the embryonic solar industry. Indeed, the intensity of media coverage increased dramatically as solar energy became a provincial election issue. We obtained this sample of articles from the Canadian Newsstand Database provided by ProQuest using the key word "solar". Originally we also included the key word "renewable," but a large number of irrelevant articles, such as wind energy, accompanied this term.

In a review of the literature on the operationalization of legitimacy, content analysis of media articles was a common method of measurement (e.g., Barron, 1998; Brown \& Deegan, 
1998; Deephouse, 1996; Lamertz \& Baum, 1998). Our use of The Windsor Star to measure legitimacy was bolstered by the fact that it enjoys one of the highest readership penetrations in Canada - 80 percent (Newspaper Audience Databank, 2012), so that news about the solar energy industry would reflect and influence the attitudes of area residents (Deephouse, 1996).

The first two authors coded the newspaper articles and any discrepancies were resolved through discussions. Each article was coded in terms of: 1) whether or not it conferred legitimacy and how it did so; 2) if and how organizational ingenuity was mentioned; and 3) if and how institutional constraints were mentioned. Constraints and ingenuity were coded in the same way as in the interview data. Of the 91 articles, 44 discussed institutional constraints, and 35 discussed organizational ingenuity. Legitimacy was coded for each article (Bansal \& Cleland, 2004; Lamertz \& Baum, 1998). Any article that discussed the solar industry in a positive or neutral manner was coded as conferring legitimacy; any article that discussed the solar industry in a negative manner was coded as questioning the legitimacy of the industry (Deephouse, 1996; Meyer \& Scott, 1983). Of the 91 articles, 65 articles in our media analysis conferred legitimacy, and 26 did not.

\section{Model development}

We used the interview and media data to develop a process model of the development of ingenuity strategies in the Ontario solar industry. This model included the identification and conceptualization of top-down institutional forces, bottom-up ingenious responses, and their emergence over time. In developing this model, we considered the applicability of different theoretical frameworks regarding the interaction of stakeholders with institutional forces (e.g., Oliver, 1991; Perkmann \& Spicer, 2007; Scully \& Meyerson, 1996; Seo \& Creed, 2002). We also applied research on the development of legitimacy, especially for new industries (e.g., 
Aldrich \& Fiol, 1994; Ashforth \& Gibbs, 1990; Drori \& Honig, 2013; Scott, 1994; Suchman, 1995). Each author developed conceptualizations and process models and sent them for review by the other authors. We developed an initial model after the first wave of interviews in 2011 and discussed it with the second round of interviewees in 2012. In our analyses of the data, we found that Oliver's (1991) framework of strategic responses to institutional processes helped position our data in theory (Suddaby, 2006). Consequently, we incorporated some of her terms into our conceptualizations. We converged after many iterations to the findings we present next.

\section{Findings}

Figure 1 presents the induced process model (Langley, 1999; Van de Ven, 2007). It depicts the relationships between the top-down institutional forces and bottom-up organizational ingenuity at four different levels of analysis in the Ontario solar energy industry from 20092012. We identified five strategies, one institutional constraint, and one institutional enabler that turned into an institutional constraint. We present these chronologically.

Insert Figure 1 about here

Industry Emergence: Institutional enabling and entrepreneurial innovation

Institutional enabler: Grid access. The implementation of the GEA allowed renewable energy to provide up to seven percent of the power to the Ontario electric distribution system, commonly referred to as "the grid". This legally sanctioned grid access was a top-down institutional force that enabled renewable energy to be part of the province's energy sources, whereas previously renewables could not exist at a sufficient scale. This legal permission provided regulatory legitimacy to the solar energy industry that was important for its emergence 
(Aldrich \& Fiol, 1994; Scott, 1995). Cognitive legitimacy existed in that the ability and desire for renewable energy to contribute up to seven percent of energy demand was not questioned as evidenced in the media data (Meyer \& Scott, 1983; Suchman, 1995).

Compliance strategy. In response to this institutional change, a variety of entrepreneurs entered the market between 2009 and 2010 to manufacture and install solar panels. These entrepreneurs were innovative because they successfully implemented new ideas in new organizations in new markets (Schumpeter, 1986; Van de Ven, 1986). Some adapted manufacturing facilities used in the auto industry. We termed this a compliance strategy (Oliver, 1991), in that entrepreneurs accepted the institutional rules and created new firms to take advantage of the opportunities the rules provided. This was not an ingenuity strategy because firm resources were not limited and institutional rules were not constraining (Lampel et al., 2011).

The compliance strategy generated considerable energy and economic impact. Investment in the renewable energy industry was substantial (\$26 billion in private investments from 20092011). Where only a few thousand clean energy jobs existed previously, over 20,000 jobs were created, 8,000 within solar energy (Ontario Ministry of Energy, 2012). By July 2012, approximately 2,500 renewable projects were approved, producing enough energy to power 1.2 million homes (Sorensen, 2012). The ten largest solar farms in the country were built in Ontario, making the province the leading solar energy producer in Canada; the 80 MW Sarnia Solar project is the largest operational solar photovoltaic farm in the world, generating enough energy to power approximately 12,000 homes a year (Ontario Ministry of Energy, 2012). The ability to create jobs and provide electricity from solar panels in Ontario enabled the industry to gain pragmatic legitimacy by providing jobs and income from electricity generation to buyers of solar 
panels. Pragmatic legitimacy was evident in news about economic issues, such as job creation, business growth, and new markets (e.g., Hall, 2011a Macaluso, 2011; Pearson, 2011), and political issues, such as the role of renewable industry in the re-election of the government (Hall, 2011d).

This ability also addressed societal concerns about the environment and employment (McAllister Opinion Research, 2010). Solar energy was portrayed as a clean and renewable source of energy providing societal benefits through reduced greenhouse gas emissions and dependency on fossil fuels. Accordingly, moral legitimacy was evidenced by news about the environment (clean, renewable energy, for example, Wolfson, 2011a), and society (local University expertise, solar panels on schools, community centers, religious buildings, houses, and government and corporate buildings, for example, Hall, 2011c). Another important benefit was the thousands of jobs already created by the solar industry and the promise of more in the future. The endorsements of local, public and private organizations that purchased solar panels also bestowed moral legitimacy as these were viewed as "progressive" organizations which took the lead in the future of clean energy in Ontario.

The seven percent limit for renewable energy specified in the GEA was reached in less than a year, however. One reason why this happened so fast was that large, well-financed wind companies moved in quickly, and the smaller solar firms were left scrambling for the remaining grid access. With the Ontario government refusing to increase the limit, the seven percent maximum changed from enabling the industry to constraining it. This resulted in an environmental jolt for the renewable energy industry (Meyer, 1982). A second institutional constraint emerged as well, political uncertainty. We address these two constraints that engendered ingenious responses in the next section. 


\section{Institutional constraints}

We identified two main institutional constraints from our data. The first was limited grid access, the inability of solar producers to connect to the grid. This theme was discussed by all 22 interviewees $(100 \%)$ and coded 61 times; it appeared in six media articles out of $91(6.5 \%)$. The second institutional constraint was political uncertainty. This theme was discussed by 16 interviewees (73\%) and coded 46 times; it appeared in 38 of the 91 media articles (42\%). Both constraints were evident immediately following the introduction of the GEA in February 2009.

Limited grid access. Interviewees agreed that connecting to the grid was the hot button issue in the Ontario solar industry. Participants in both waves of interviews were quick to express their frustrations with the limit, often within the first few minutes of the interview. For example: "A lot of what's holding the industry back right now is the connectivity to the grid...that's really holding back this kind of massive explosion in Ontario right now."

A consistent reason given for the lack of grid access was the failure to transition from a centralized to a decentralized energy system. The existing centralized generation and distribution functions of the current Ontario electricity industry created barriers to grid access. One participant noted:

When any country decides to get into renewable energy there is a change in concept from centralized generation of energy to decentralized; that puts a great strain on the actual grid resources.

In the case of solar energy, each individual solar panel installation becomes an energy

provider. Thus, the system transitions from centralized with a single energy provider to decentralized with multiple providers. Not surprisingly, the centralized OPA was hesitant to give up its monopolistic power. As explained by one participant: "If you're used to a central power 
system and you are the monopoly holder, then your life is comfortable because you have perfect control, you're the only entity."

A second and related reason for limited grid capacity discussed by participants was resource constraints, especially related to technical, human, and knowledge constraints in the OPA. For example:

The problem that I find here in Ontario is that when they developed the Green Energy Act, they didn't really allocate the resources to go through that change which we all knew was hard but nobody expected it to be disastrous. There is a lack of human resources even to process the paperwork; there is a lack of technical resources out in the field to do the grid.

The participants also found it difficult to understand why resources were limited given that the issue of grid access is not unique to Canada:

So what they say is that the theoretical disturbances that renewables may create in the grid are not that big and you can have at least 15 percent of renewables in any given grid. That is the minimum that they say that you can have. That is a theoretical thing that some engineers do in the world. If you go to a place like Germany or Spain that have been operating this kind of situation already for years, they have raised this bar to 30 percent.

Perhaps most striking about this constraint was the extent to which it hurt the industry.

The seven percent maximum restriction to grid access was quickly reached, and there were no proposals by the government to increase it. This meant that all companies we examined were running below capacity, and one company was forced to layoff over 70 employees and ultimately had to close during our study period. According to an exasperated participant:

It was going to be a 400-megawatt [market] a year. That was the international predictions from sources, credible sources. That's what everyone thought; it's worth stepping into the market. We wanted 10 percent of the market share... this is a 50 megawatt facility and today, July 14, there are eight megawatts in operation. So that's two per cent of the yearly projection. It's not like you're a bit off the estimate... it's a complete failure... So there's no real way for you to overcome these problems. 
When the seven percent limit was reached, and thus became an institutional constraint, the nature of the legitimacy of the industry changed as well. Whether renewables should exceed this limit was questioned, and such questioning demonstrated a lack of cognitive legitimacy for industry expansion beyond the seven percent limit (Meyer \& Scott, 1983; Suchman, 1995). There was no longer pragmatic legitimacy for the installation of more solar panels tied to the grid because consumers could not sell excess power back to the grid. However, moral legitimacy did persist because solar energy could help alleviate continuing societal concerns about the environment and employment.

Political uncertainty. Our first wave of interviews was conducted in Summer 2011, the quarter preceding the provincial election. At that time, voters appeared equally split between the two main parties who had opposing views of the renewable energy industry. In particular, the incumbent Liberals promised to redouble their renewable energy efforts and to maintain the GEA, whereas the opposition Conservatives promised to repeal the GEA. Although it was possible that the program would only change in name and details, our participants viewed this as a serious threat to the viability of their businesses. One participant stated bluntly: "And of course then you've got the election in the Fall right? That's going to mess things up."

Politicians introduced a new level of uncertainty that represented a dramatic institutional constraint. For example, investors hesitated to invest further, and customers were unwilling to purchase and install solar panels. A participant noted that: "The opposition making statements about the industry before the election...that puts everything on hold. If he (Mike Hudak, Conservative party leader) says in six months, 'What I want, is to stop all this', no one's going to do anything." The uncertain future of the GEA was also widely covered in the media, and 10 articles focused on this issue (e.g., Wolfson, 2011b). 
This politicizing of solar energy created confusion because political party platforms profiled in the media referenced differing data with conflicting results. Seemingly easy questions to answer, such as the cost to consumers and the province, the number of jobs created, and the amount of power produced, became enigmas that generated uncertainty:

When people say, what's the cost to create these green energy jobs? There are 17 different numbers out there. That's when the government is in a number of these initiatives and is not fact-based, or not transparent, it's very hard to actually validate or debug myths.

Although the Liberal party that was pro-GEA was re-elected in Fall 2011, the second wave of interviews conducted in Fall 2012 highlighted a continuing political uneasiness. High profile media coverage of rising electricity rates following the introduction of higher priced green energy development created pressure for the Liberal government to decrease the FIT rate for solar and wind energy. Subsequently, the rate for solar rooftop panels that generate less than $10 \mathrm{kWh}$ (kilowatt hour) of energy, such as those on residences, was reduced from $80.2 \notin / \mathrm{kWh}$ to the current $54.9 \phi / \mathrm{kWh}$. Consequently, it became less lucrative to invest in these panels based on profits from selling the energy to the grid (Beneteau, 2011). The media reported:

The local solar industry said reducing the price of solar production won't kill the market, but might slow its growth. "There are two components: one is the return on the investment and other is being able to obtain financing," local lawyer and solar investor Paul Mullins said. "Obtaining financing will be difficult." (Wolfson, 2011c).

Many interviewees reported that political decisions based on short-term political maneuvering were not in the best interest of business or the long-term interest of the province. A solar panel manufacturer said:

...this should not be a political debate. The energy model of a country is just as important as the army or foreign relations or health or education, and you can't change those things every four years. You can tweak it, you can modify things in the plan, but you need to have a long-term commitment to change these things. The grid is going to last $20-30$ years. Generation investment is for $20-30$ years. We 
can't depend on elections every four years. If kids go to school for 12 years, you can't change the education every four years. You can't debate every four years if you want to have an army or not...there are certain things that shouldn't be debated. So that is the biggest hindrance for this industry-is the political debate before elections.

In the media, a local landowner whose family had farmed the land for generations noted that political comments about ending the green energy deals were "very frightening to people in the county" because farmers were eager to host wind turbines and solar panels (Cross, 2011a).

In spite of the political uncertainty, there was considerable public sentiment that green energy was important and should be addressed by the politicians. This sentiment included the business community, as evident from a membership survey by the local Chamber of Commerce:

Not surprisingly a plan for jobs and economic growth were at the top of the list. Also near the top of the list was energy/power - supply, cost and reliability. This was interesting because the energy/power issue did not show up in the federal election just a few months ago or in the municipal election last year (Jones, 2011).

With the appearance of these institutional constraints, industry participants responded with four ingenious strategies. We now address these in the order in which they appeared.

\section{Ingenuity Strategies}

Ingenuity was evident in the interviews with all 22 participants. The ingenuity theme was coded 59 times, 34 of which were about the formation of collaborations and 25 about innovative products and markets. In the media data, the ingenuity theme was coded 36 times in our 91 articles, with 19 articles discussing collaborations and 17 discussing innovative products and markets. We identified four types of ingenuity strategies: 1) constraint-challenging multistakeholder collaborations, 2) constraint-escaping new product and market development, 3) constraint-complying new product partnerships, and 4) constraint-escaping new product partnerships. 
Constraint-challenging multi-stakeholder collaborations. We identified the formation of multi-stakeholder collaborations to challenge the institutional constraints as the first ingenuity strategy. This strategy is consistent with past research that has found stakeholders can drive change through the formation of collaborations (DiMaggio, 1998; Dorado, 2005; Reay \& Hinings, 2009). We follow Oliver (1991) and use the term challenge, because our sample of participants consistently challenged the rationality of the two identified institutional constraints. In both the interviews and media data we found "unequivocal rejection of institutional norms and expectations;" interviewees' willingness to share frustrations with the public and us represented a belief that they had "little to lose by displaying their antagonism toward the constituents that judge or oppose them" (Oliver, 1991, p. 157). Rejection and antagonism were apparent in the first few minutes of our interviews (in a number of cases participants were visibly disturbed), and by the frequent diatribes in the media by people baffled by the two identified institutional constraints. Media articles in just one week reflected this frustration in their titles, for example: "Making pollution cheaper for everyone" (Heartfield, 2011); "Those 200 jobs are a pathetic ransom" (Fuschi, 2011); "Green energy sector frets over vote" (Hall, 2011b); and "No need for more tax in Ontario" (Sterling, 2011). We suggest that the willingness of stakeholders to challenge the institutional constraints led them to form collaborations that were viewed as a legitimate way to challenge constraints. As expressed by one participant:

“...if you work together, we're all in the same boat, we're here together. If the political environment changes, it changes for everybody. Like if we try to stand up and say something to the government, [it's better] if we have a united voice than if we do it individually."

Through collaborations, diverse and sometimes competing stakeholders ingeniously combined their resources to resist and influence the institutional constraints, mobilizing their resources in an attempt to drive institutional change (Dorado, 2005). For instance, an ad hoc 
collaboration of stakeholders planned to spend $\$ 10,000$ on advertising to educate the public about solar options and their economic impact (Wolfson, 2012b). Individually, few stakeholders had sufficient resources for such informational advertising, such as the self-employed installer of solar panels whom we interviewed. Another example included scientists and green energy officials gathered at the local university to discuss system connection constraints and how to lobby for change (Wolfson, 2011a). Lastly, a compelling example of a multi-stakeholder collaboration described by Battagello (2011a) in The Windsor Star was an unexpected alliance of interests between business and environmentalists.

Greenpeace Canada and a local solar panel company unveiled a mock memorial cemetery Wednesday to signify the death of green energy jobs across Ontario if Conservative Leader Tim Hudak is elected premier Oct. 6.

Building on the global growth of associations and trade fairs like Intersolar, emerging Ontario associations extended membership to an expanded renewables ecosystem including investors, economic development agencies, and labor unions. The inclusion of such third-party stakeholders contributed to building the industry's legitimacy (Aldrich \& Fiol, 1994). For example, these associations were able to commission independent studies to provide unbiased information to the public and government on the Ontario solar industry. One CEO expressed a need for an even greater and more powerful association that could be instrumental in forming a national energy policy that overcame political barriers and constraints: "What we very much need is a national energy policy...We need something that can bridge these four year election cycles that make it such a political issue."

Particularly ingenious about the collaborations were their dissemination strategies. For example, when using the media to convey information to the general public, the collaborations would frequently discuss the issue of job creation, which was highly salient given the province's 
reliance on the struggling manufacturing sector. Investment in renewable forms of energy and solar in particular were promoted as a way to create jobs. Our participants described how collaborations allowed them to express their frustration at how the limited access to the power grid stifled job creation and created layoffs. The Windsor Star, sensitive to job creation and the stimulation of the economy, often clearly sided with solar companies and their ability to create jobs. For example, this editorial voiced strong opinions against the government that was portrayed as the cause of the layoffs and reduced work:

The high cost of energy is related to old delivery systems and a failure to maintain infrastructure. It's the bitter pill Ontarians have had to swallow because of a series of bad moves that occurred under both the Tories and the Liberals (Beneteau, 2011).

The Windsor Star also frequently interviewed frustrated front-line employees who openly expressed their anger at the situation (e.g., Wolfson, 2011e). Local greenhouse growers also joined the renewables chorus. Constrained by inadequate power grid capacity, they lobbied heavily for a new power line that would allow them to move forward with 500 more acres under glass (Cross, 2011b).

As has been found in research examining institutional entrepreneurship (Creed et al. 2002; Lounsbury et al. 2003; Rao 1998), stakeholders legitimized their grievances against the institutional constraints by framing them within popular social discourses, thus furthering their moral legitimacy.

In sum, collaborations effectively used the media to garner public support and challenge the institutional constraints. Collaborations required a relatively small commitment of organizational resources, as firms tried to alter the constraints while operating as usual. Uniting with multiple stakeholders imaginatively brought together resources to enter a new domain of action: political activity to alter constraints (Lampel et al., 2011). Ultimately, however, this 
strategy was unsuccessful at changing the institutional constraints. This is graphically portrayed in Figure 1 by the thick arrow that is rebuffed by the institutional constraints.

Constraint-escaping new product and market development. With the failure of the first ingenuity strategy, a second strategy quickly emerged, constraint-escaping new product and market development. It was here that we witnessed internal transitions within individual firms. They recognized both the severity of the constraints and their inability to alter them. In response, they began to create ingenious solutions to adapt to the constraints and enter new domains of action. We follow Oliver (1991) and use the term escape to refer to firms changing activities and domains (Thompson, 1967). Entrepreneurs recognized the difficulty in changing constraints and so developed customized products and niche markets that represented the internal organizational change needed to survive the institutional environment.

This strategy emerged in 2010, but it accelerated between the summer of 2011 and the summer of 2012. A number of companies developed a variety of products that functioned independent of grid access. For example, an entrepreneur proudly announced that his company had developed a solar kiosk/bar that provided refrigeration and did not require access to the power grid. Solar-powered golf carts were sold to a local golf course, creating 10 full-time jobs and the installation of a 125-kilowatt rooftop project (Wolfson, 2012a). Other interesting examples were a solar cooker (Wolfson, 2012b) and a solar recharging station and bench for smartphones and laptops (Schmidt, 2012).

The constrained local market also prompted local entrepreneurs to consider export opportunities and new markets. For example, a solar-powered pump targeting the African market was developed (Wolfson, 2012a). In addition, two media articles (Battagello, 2011b; Hall, 2011d) and two CEOs (one in the first round of interviews and one in the second round) 
discussed newly developed products by local manufacturers that specifically targeted the adjacent United States market for sales while avoiding the constraints imposed in the Ontario market. One CEO of a local solar panel manufacturer summarized his strategy:

...because no one can get connected, there's no demand domestically in the province. Now you have your export, that's where the future truly is. That's where we're looking at right now; we're marketing down in the States a lot.

While the second ingenuity strategy was being developed and implemented, stakeholders continued to use the first ingenuity strategy and challenged the institutional constraints, albeit unsuccessfully. Without the second ingenuity strategy, organizations were not likely to survive, as evidenced by an international company that was forced to shut down. Their seven million dollar plant was closed in Spring 2012, and nearly 100 employees lost their jobs. This plant was the only one to fail in our study, and the company was quick to blame limited access to the grid as the reason for their closure. In contrast, the government (both the provincial finance minister and the city's mayor were interviewed in the article) blamed the company for its lack of competitiveness (Schmidt \& Hall, 2012).

Indeed, the remaining Ontario-based companies exercised ingenuity that enabled them to circumvent the constraints. We depict this ingenious adaptation with a thick arrow in Figure 1 that goes around the top down constraints. In terms of Lampel et al. (2011), this appears to be what they called bypassing constraints, a topic that received limited attention in the call for papers compared to changing the institutional constraints or adapting to the constraints.

Constraint-complying new product partnerships. We subsequently observed a third ingenuity strategy, which was the development of new product partnerships that found niches within the Ontario power grid. We use Oliver's (1991, p. 153) term complying in this ingenuity 
strategy because the partners acquiesced to the institutional constraints while "consciously and strategically" complying in anticipation of "self-serving benefits".

There were a few examples of this strategy. One was a partnership between a solar energy start-up company and the University of Windsor who together worked to develop a new system that automatically shut off power from traditional energy sources when solar power was being produced (Macaluso, 2012). It was estimated that the new system could reduce electricity bills by as much as 70 per cent. Another constraint-complying strategy emerged when a solar startup CEO and a solar aggregator agreed to partner to overcome limited grid access by paying for their own upgrades to the power lines to a decentralized energy system. The upgraded power lines represented a form of new product development. Notably, no organization could implement this ingenious solution on its own; instead, our participants were willing to pool limited organizational resources and jointly incur short-term costs for long-term gain (Wolfson, 2011d).

This third ingenuity strategy was innovative because it used constraint-complying new product development in partnerships, a type of organization that was new to the participants (Rogers, 1983; Schumpeter, 1986). This is depicted by thick arrows in Figure 1 with the strategy incorporating both bottom-up ingenuity and top-down constraints. Moreover, this opportunitybased approach combined the original compliance strategy with the collaborative strategy they displayed as the seven percent cap began to threaten their survival. The thinner arrows in Figure 1 represent this synthesis of previous strategies. Stakeholders learned that collaborations could be effective when combined with compliance instead of challenge.

Constraint-escaping new product partnerships. The final ingenuity strategy we observed again involved elements of previous strategies; here, partnerships developed new products that enabled firms to escape the constraints (Oliver, 1991). For example, a solar panel manufacturer 
joined with a company that made ground-mounted solar systems that would reduce labor costs by as much as 90 percent and increase efficiency to the point where "our first system was shipped, installed and commissioned all on the same day" (Hall, 2012). This partnership reduced the political uncertainty by driving down costs making the use of solar panels more economically legitimate. A second example of this strategy was a partnership between a local solar manufacturer and a collaboration of researchers at the University of Windsor who together developed a grid-independent solar carport (Wright, 2011).

From the second ingenuity strategy that appeared in 2010, stakeholders had learned an effective means to get around the institutional constraints, namely, by developing new, gridindependent products and extending into markets outside of Ontario. Moreover, since we found evidence of collaborations as early as 2009, it makes sense that by 2012 the greater connectedness among stakeholders would bear new fruit. Accordingly, by 2012 the final ingenuity strategy became apparent, and it combined the effective escape tactic from the second ingenuity strategy with developing partnerships that first began to form in the first ingenuity strategy. Once again, the thinner arrows in Figure 1 represent this synthesis of previous strategies. And as shown by the thick arrow in Figure 1, this strategy was effective at circumventing the institutional constraints.

Ingenuity and legitimacy. Although our first identified ingenuity strategy was not successful at complying with or escaping the constraints, our second, third and fourth ingenuity strategies were. Part of their success was that stakeholders were able to extend their existing stock of legitimacy to the new products and markets resulting from the strategies (Ashforth \& Gibbs, 1990). The ability of solar panels to provide electric power to customers who were not connected to the Ontario power grid demonstrated pragmatic legitimacy. Stakeholders also built 
on a base of regulative and moral legitimacy established by the politicians and the public by developing products that did not contravene the regulations, by continuing to position these products as 'green,' and by continuing to provide jobs in an area hard hit by the decline in the automobile industry. Moreover, these new products did not require government subsidies, an issue that before had raised considerable questions from politicians and in the media (Sterling, 2011). No media articles questioned the new products or markets, suggesting cognitive legitimacy (Deephouse \& Suchman, 2008; Meyer \& Scott, 1983). Lastly, we found that when an individual firm extended legitimacy to its new products or markets, the legitimacy of the entire industry benefited. That is, through firm-level and partnership-level ingenuity strategies, the industry garnered legitimacy by demonstrating independence of government subsidies and the grid, thus demonstrating a free-market approach.

\section{Contributions and Implications}

Research. Scholarly work on new constructs usually includes the important work of enhancing the clarity of definitions and measures (Kaplan, 1964; Suddaby, 2010a). Our first contribution to research is enhancing the conceptual clarity of the construct of ingenuity. We found that ingenuity strategies could be usefully framed using Oliver's (1991) responses to institutional processes, in our case, compliance, challenge, and escape. Two implications for future research are seeing if these three responses appear in other settings and if other responses elaborated by Oliver (1991) are useful for classifying ingenuity.

Past research on institutions and institutional entrepreneurship recommends greater attention to bottom-up processes of institutional creation (Scott, 1994; Suddaby, 2010b) and to dynamic models of how institutions form, change, and decline (Barley \& Tolbert, 1997; 
Greenwood et al., 2002; Perkmann \& Spicer, 2007). Our second contribution is inducing a process model of bottom-up ingenuity in response to top-down institutional pressures. We found that ingenuity developed over time in a sequence of strategic responses characterized by challenge, escape, compliance, and escape. Future research might investigate how organizational ingenuity unfolds over time in other industries, the different strategies employed, and the sequence in which they are manifested.

Legitimacy is necessary for surviving in strong institutional environments (Greenwood et al., 2002; Meyer \& Rowan, 1977), such as those where ingenuity is needed. Our third contribution is showing how industry participants capitalized on existing stocks of legitimacy in developing their ingenuity strategies, specifically how pragmatic, regulative, moral, and cognitive legitimacy applied to them. Our research using different dimensions of legitimacy further develops the claim that changes can be legitimized by framing them within popular discourses (Creed et al., 2002; Deephouse, 1996; Lounsbury et al., 2003; Perkmann \& Spicer 2007; Rao 1998). The relationship between different types of ingenuity and different dimensions of legitimacy over time should be examined further in other contexts.

A central question for research on ingenuity is: "Under what conditions does organizational ingenuity emerge?" (Lampel et al., 2011, p. 459). Our fourth contribution is identifying one condition when ingenuity emerged, specifically, when an institutional enabler became an institutional constraint. This occurred even though the institution itself, the GEA, did not change. Instead, successful entrepreneurial innovation quickly filled the capacity of the renewable energy market in Ontario. At this point, innovation took place within institutional constraints, consistent with the definition of ingenuity (Lampel et al., 2011). 
Past research has shown that collaborations are important in driving institutional change (Dorado, 2005; Greenwood et al., 2002; Perkmann \& Spicer, 2007; Reay \& Hinings, 2009), and we found collaborations in the Ontario solar energy industry. What makes this a contribution is the speed at which they appeared; collaborations began to form within the first year of the introduction of the GEA. The rapid appearance of collaborations was unexpected, based on past theorizing about legitimacy in embryonic industries by Aldrich and Fiol (1994, p. 655): "Collective action is extremely difficult to organize early in the life of an industry due to free rider problems." We propose that collaborations in embryonic industries happen faster when institutional constraints are stronger; future research could test this proposition.

Policy. The implications of this study for the Ontario solar industry are dramatic. Without changes to the current institutional constraints the industry is unlikely to grow beyond its current form and a promising opportunity for clean energy, investment, and job creation will be lost. Firms are looking outside of Ontario to expand and to stay in business, and the firm of one of our interview participants was forced to close. Further, Ontario will not reduce dependence on fossil fuels, an important topic for policy makers and researchers alike (CBC News, 2011; Okereke, Wittneben, \& Bowen, 2012; Wittneben, Okereke, Banerjee, \& Levy, 2009).

Currently, according to recent REN 21 Renewables Global Status Reports, North American solar companies lag behind global solar competitors (Sawin 2011; 2012). Our interviewees consistently demonstrated a strong grasp of the global solar industry, market and stakeholders. All participants acknowledged that they sought out innovation overseas, primarily in Europe. This echoes a recent report by IHS Emerging Energy Research (2011) that notes "Europe has become the testing ground for the latest generation of solar technologies including thermal storage, CPV [concentrated photovoltaics], and innovative PV [photovoltaics] 
technologies." This should be of particular concern to the Canadian government as the GEA was created to spur innovation within the province and potentially be the first of many Acts for the rest of Canada. With the seven percent grid restriction, our participants indicated that many people (such as investors, customers, engineers) were unwilling to invest resources in Canada.

Our study highlights a need for all relevant stakeholders, including private, public and non-profit entities, to be at the policy table if sustainable climate change policies are to be successfully introduced (Okereke et al., 2012). This is consistent with past research that has found that such multi-stakeholder partnerships are essential to address existing regulatory, participation, resource and learning gaps (Pinkse \& Kolk, 2012; Wijen \& Ansari, 2007).

Managers. In the Ontario solar industry, the seven percent restriction changed from enabling to constraining within less than one year. Managers should be aware of how quickly such a change can occur so they might preemptively strike at the institutional constraints.

It is not surprising that the first ingenuity strategy (constraint-challenging multistakeholder collaborations) represented a relatively small transition within the organizations we studied. Essentially, stakeholders sought to change the constraints with minimal investment and by continuing business as usual (making solar panels for the Ontario market that required grid access). It makes sense for organizational stakeholders to first seek to change constraints with a minimal commitment of resources. What is important for managers is that within one year, the firms that survived in our sample realized that this strategy was not effective and rapidly changed. At this point they were forced to commit significant resources to develop new products that could sell independent of grid access. Thus managers must quickly surmise the severity of the constraints and their ability to alter them and exercise the appropriate ingenuity strategy. Our 
study delineated one way for organizations to change and step around severe institutional constraints by developing new products and markets, sometimes in partnership with others.

\section{Limitations}

The qualitative nature of our study limits its literal generalization beyond the context of the solar industry in Ontario. However, it provides insight about an embryonic industry that could be a benchmark to others, namely in examining the role of ingenuity, institutional constraints and legitimacy in embedded agency and in the process of institutional change. Future researchers might examine other industries to see how the process differs, including additional ingenuity strategies that emerge under different institutional constraints.

Furthermore, the industry is highly concentrated in the southern part of Ontario, and correspondingly this was our main area of investigation. Most of our interviewees lived there, and our media data were obtained from a single source. Future research could investigate if similar findings emerge in other places where solar energy is being developed and where ingenuity in the face of institutional constraints is exercised.

Lastly, we defined organizational ingenuity as an ability, yet we were only able to observe its outcomes. Similar concerns have existed for other constructs, like dynamic capabilities and agility. As this new construct of organizational ingenuity is further developed, future research will need to tease out its nature as trait, skill, action, or outcome.

\section{Conclusion}

We used a case study of the Ontario solar energy industry to build theory on the emerging construct of organizational ingenuity (Eisenhardt, 1989; Lampel et al., 2011). Because ingenuity 
takes place within institutional constraints (Lampel et al., 2011), we used institutional theory to orient our research (Suddaby, 2006). Our research question asked about the role of organizational ingenuity in the paradox of embedded agency (Seo \& Creed, 2002). We induced a process model of ingenuity that incorporated top-down pressure at the industry level manifested by institutional constraints and bottom-up change at the firm level (Barley \& Tolbert, 1997; Greenwood et al., 2002; Perkmann \& Spicer, 2007; Scott, 1994; Suddaby, 2010b). We found that severe top-down constraints lead to a set of bottom-up ingenuity strategies that challenged, complied with, or escaped the constraints. These ingenuity strategies were manifested at multiple levels of analysis, and firms were able to extend different dimensions of legitimacy to the strategies. Hence, when confronted by significant institutional constraints, we conclude that firms can circumvent these constraints ingeniously and legitimately. 


\section{References}

Aldrich, H. E., \& Fiol, C. M. (1994). Fools rush in? The institutional context of industry creation. Academy of Management Review, 19, 645-670.

Amabile, T., Conti, R., Coon, H., Lazenby, J., \& Herron, M. (1996). Assessing the work environment for creativity. Academy of Management Journal, 39, 1154-1184.

Ashforth, B., \& Gibbs, B. (1990). The double-edge of organizational legitimation. Organization Science, 1, 177-194.

Bansal, P., \& Clelland, I. (2004). Talking trash: Legitimacy, impression management, and unsystematic risk in the context of the natural environment. Academy of Management Journal, 47, 93-103.

Barley, S., \& Tolbert, P. (1997). Institutionalization and structuration: Studying the links between action and institution. Organization Studies, 18, 93-117.

Barron, D. M. (1998). Pathways to legitimacy among consumer loan providers in New York City, 1914-1934. Organization Studies, 19, 207-33.

Battagello, D. (2011a). Greenpeace calls Hudak a job killer. The Windsor Star, September 29, 2011.

Battagello, D. (2011b). Local firm expanding. The Windsor Star, October 11, 2011.

Beneteau, M (2011). School board puts solar panels on hold. The Windsor Star, November 3, 2011.

Brown, N., \& Deegan, C. (1998). The public disclosure of environmental performance information- a dual test of media agenda setting theory and legitimacy theory. Accounting and Business Research, 29, 21-41.

CBC News. (2011). Canada's power grid needs \$293 billion infusion: report. April 7, 2011. http://www.cbc.ca/news/canada/story/2011/04/06/canada-power-grid-investment.html.

Creed, W. E. D., Scully, M.A., \& Austin, J. R. (2002) .Clothes make the person: The tailoring of legitimating accounts and the social construction of identity. Organization Science, 13(5): 475-496.

Cross, B. (2011a). 3 battle for Crozier's crown. The Windsor Star, September 30, 2011.

Cross, B. (2011b). Duncan sparks power line review: 1000 jobs in jeopardy. The Windsor Star, November 26, 2011.

Deephouse, D. (1996). Does isomorphism legitimate? Academy of Management Journal, 39, 1024-1039.

Deephouse, D. L., \& Suchman, M. (2008). Legitimacy in organizational institutionalism. In R. Greenwood, C. Oliver, R. Suddaby, \& K. Sahlin (Eds.), The Sage handbook of organizational institutionalism (pp. 49-77). Thousand Oaks, CA: Sage.

DiMaggio, P. (1988). Interest and agency in institutional theory. In L. G. Zucker (Ed.), Institutional patterns and organizations: Culture and environment (pp. 3-21). Cambridge, MA: Ballinger. 
DiMaggio, P. J., \& Powell, W. W. (1983). The iron cage revisited: Institutional isomorphism and collective rationality in organizational fields. American Sociological Review, 48, 147160.

Dorado, S. (2005). Institutional entrepreneurship, partaking and convening. Organization Studies, 26, 385-414.

Drori, I., \& Honig, B. (2013). A process model of internal and external legitimacy. Organization Studies, 34, 345-376.

Eisenhardt, K. M. (1989). Building theories from case study research. Academy of Management Review, 14, 532-550.

Eisenhardt, K. M., \& Graebner, M. E. (2007). Theory building from cases: Opportunities and challenges. Academy of Management Journal, 50, 25-32.

Fuschi, R. (2011). Those 200 jobs are a pathetic ransom. The Windsor Star, September 24, 2011.

Garud, R., Jain, S., \& Kumaraswamy, A. (2002). Institutional entrepreneurship in the sponsorship of common technological standards: The case of Sun Microsystems and Java. Academy of Management Journal, 45(1), 196-214.

Garud, R., Hardy, C., \& Maguire, S. (2007). Institutional entrepreneurship as embedded agency: An introduction to the special issue. Organization Studies, 28, 957-969.

Goldman, S.L., Nagel, R.N., \& Preiss, K. (1995). Agile Competitors and Virtual Organizations. New York: Van Nostrand Reinhold.

Greenwood, R., Suddaby, R., \& Hinings, C. R. (2002). Theorizing change: The role of professional associations in the transformation of institutionalized fields. Academy of Management Journal, 45, 58-80.

Hall, D. (2011a). Unconquered-sustainable deal reduces cost of solar systems. The Windsor Star, June 16, 2011.

Hall, D. (2011b). Green energy sector frets over vote. The Windsor Star, September 24, 2011.

Hall, D. (2011c). Windsor Islamic centre to produce solar power. The Windsor Star, October 5, 2011.

Hall, D. (2011d). Renewable energy brighter after vote: Many local firms are expanding. The Windsor Star, October 15, 2011.

Hall, D. (2012). Solar tech company, golf club partner up. The Windsor Star, May 17, 2012.

Heartfield K. (2011). Making pollution cheaper for everyone. The Windsor Star, September 26, 2011.

Heugens, P. P. M. A. R., \& Lander, M. W. (2009). Structure! Agency! (and other quarrels): A meta-analysis of institutional theories of organization. Academy of Management Journal, 52, 61-85.

IHS Emerging Energy Research. (2011). U.S. solar power: Markets and strategies 2011-2025. June 2011, 207 pp. Accessed July 22, 2011 at www.emerging-energy.com.

Jarvis, A. (2011). Hudak can't talk the talk, PC leader wouldn't answer biggest question in Windsor, Essex County. The Windsor Star, September 15, 2011. 
Jarzabkowski, P. (2004). Strategy as practice: Recursiveness, adaptation, and practices-in-use. Organization Studies, 25: 529-560.

Jones, J. (2011). Chamber issues: Job creation and growth. The Windsor Star, September 26, 2011.

Kaplan A. 1964. The conduct of inquiry. Chandler: New York.

Lamertz, K., \& Baum, J. A. C. (1998). The legitimacy of organizational downsizing in Canada:An analysis of explanatory media accounts. Canadian Journal of Administrative Sciences, 15, 93-107.

Lampel, J., Honig, B., \& Drori, I. (2011). Discovering creativity in necessity: Organizational ingenuity under institutional constraints. Organization Studies, 32, 458-460.

Langley, A. (1999). Strategies for theorizing from process data. Academy of Management Review, 24, 691-710.

Lawrence, T. B., \& Suddaby, R. (2006). Institutions and institutional work. In S. R. Clegg, C. Hardy, T. B. Lawrence, \& W. R. Nord (Eds.) Handbook of organization studies, $2^{\text {nd }}$ Edition (pp. 215-254). London: Sage.

Lounsbury, M., Ventresca, M. J., \& Hirsch, P. (2003). Social movements, field frames, and industry emergence. Socio-Economic Review, 1(1), 71-104.

Lu, Y., \& Ramamurthy, K. (2011). Understanding the link between information technology capability and organizational agility: An empirical examination. MIS Quarterly, 35, 931954.

Macaluso, G. (2011). Chrysler warehouse to bolster region's tax base: Pillette site reborn. The Windsor Star, October 18, 2011.

Macaluso, G. (2012). 'Switching' to solar electricity. The Windsor Star, April 28, 2012.

Margolis, J. D., \& Molinsky, A. (2008). Navigating the bind of necessary evils: Psychological engagement and the production of interpersonally sensitive behavior. Academy of Management Journal, 51, 847-872.

McAllister Opinion Research. (2010). The 2010 Global Thought Survey on Sustainability. Pembina Institute. June 24, 2010. Accessed March 12, 2013 at http://www.pembina.org/pub/2040.

Meyer, A. D. (1982). Adapting to environmental jolts. Administrative Science Quarterly, 27: 525-537.

Meyer, J. W., \& Rowan, B. (1977). Institutional organizations: Formal structure as myth and ceremony. American Journal of Sociology, 83, 340-363.

Meyer, J. W. and W. R. Scott (1983). Centralization and the legitimacy problems of local government. In J. W. Meyer and W. R. Scott (eds.) Organizational environments: Ritual and rationality. Beverly Hills, CA, Sage: 199-215.

Mezias, S. J. (1990). An institutional model of organizational practice: Financial reporting at the Fortune 200. Administrative Science Quarterly, 35: 431-457.

Newspaper Audience Databank. (2012). http://nadbank.com/en/study/readership/totalweekly. 
Okereke, C., Wittneben, B., \& Bowen, F. (2012). Climate Change: Challenging Business, Transforming Politics. Business \& Society, 51, 7-30.

Oliver, C. (1991). Strategic responses to institutional processes. Academy of Management Review, 16, 145-179.

Ontario Ministry of Energy. (2012). http://www.energy.gov.on.ca/en/green-energy-act/.

Pearson, C. (2011). An autoworker's green haven: Firm hires industry's unemployed. The Windsor Star, September 19, 2011.

Perkmann, M., \& Spicer, A. (2007). Healing the scars of history: Projects, skills and field strategies in institutional entrepreneurship. Organization Studies, 28(07), 1101-1122.

Pinkse, J. \& Kolk, A. (2012). Addressing the Climate Change-Sustainable Development Nexus: The Role of Multi-stakeholder Partnerships. Business \& Society, 51, 176-210.

Postmedia News. (2011). Alternative to tapping into solar power. The Windsor Star, September $17,2011$.

Rao, H. (1998). Caveat emptor: The construction of nonprofit consumer watchdog organizations. American Journal of Sociology, 103(4), 912-961.

Reay, T., \& Hinings, C. R. (2009). Managing the rivalry of competing institutional logics. Organization Studies, 30, 629-652.

Rogers, E. M. (1983). Diffusion of Innovations (3rd ed.). New York: Free Press.

Roth, A. (1996). Achieving strategic agility through Economies of Knowledge. Strategy \& Leadership, 24, $30-36$.

Sambamurthy, V., Bharadwaj, A., \& Grover, V. (2003). Shaping agility through digital options: Reconceptualizing the role of information technology in contemporary firms. MIS Quarterly, 27, 237-263.

Sawin, J. (2011). Renewable Energy Policy Network for the $21^{\text {st }}$ Century: Renewables 2011 Global Status Report. REN21 Secretariat, Paris, France. accessed October 3, 2011 at www.ren21.net.

Sawin, J. (2012). Renewable Energy Policy Network for the $21^{\text {st }}$ Century: Renewables 2012 Global Status Report. REN21 Secretariat, Paris, France. accessed February 26, 2013 at www.ren21.net.

Schmidt, D. (2012). Sit down and plug into the sun. The Windsor Star, September 28, 2012.

Schmidt, D., \& Hall, D. (2012). Solar tech manufacturer Siliken closes Windsor operations. The Windsor Star, May 11, 2012.

Schumpeter, J. A. (1986). The process of creative destruction. In J. B. Barney \& W. G. Ouchi (Eds.), Organizational economics (pp. 408-413). San Francisco CA: Jossey-Bass.

Scott, R. W. (1994). Institutions and organizations: Toward a theoretical synthesis. In W. R. Scott, J. W. Meyer, and Associates (eds.), Institutional Environments and Organizations: Structural Complexity and Individualism. Thousand Oaks, CA, Sage: 55-80.

Scott, R. W. (2008). Institutions and Organizations: Ideas and Interests. Sage Publications. 
Scully, M. \& Meyerson, D. (1996). Before isomorphism: The dynamics of legitimation during implementation of corporate ethics programs. Working paper, Sloan, MIT, Cambridge, MA.

Seo, M., \& Creed, W. E. D. (2002). Institutional contradictions, praxis, and institutional change: A dialectical perspective. Academy of Management Review, 27, 222-247.

Sorensen, C. (2012). Grey Skies for the Energy Industry. Macleans. July 10, 2012. Accessed March 15, 2012 at http://www2.macleans.ca/2012/07/10/solar-flame-out/

Strang, D. B., \& Meyer J. W. B. (1993). Institutional conditions for diffusion. Theory and Society, 22(4), 487-511.

Sterling, C. (2011). No need for more tax in Ontario. The Windsor Star, September 28, 2011.

Strauss, A. L., \& Corbin, J., 1998. Basics of qualitative research: Techniques and procedures for developing grounded theory, Sage, Thousand Oaks.

Suchman, M. C. (1995). Managing legitimacy: Strategic and institutional approaches. Academy of Management Review, 20, 571-610.

Suddaby, R. (2006) From the editors: What grounded theory is not. Academy of Management Journal, 49 (4), 633-642.

Suddaby R. (2010a). Editor's Comments: Construct Clarity in Theories of Management and Organization. Academy of Management Review, 35(3): 346-357.

Suddaby, R. (2010b). Challenges for institutional theory. Journal of Management Inquiry. 19, 14-20.

Sull, D. (2010). Competing through organizational agility. McKinsey Quarterly, 1, 48-56.

Thompson, J. D. (1967). Organizations in Action. New York, McGraw-Hill.

Tolbert, P. S., \& Zucker, L. G. (1996). The institutionalization of institutional theory. S. R. Clegg, C., Hardy, W. R. Nord, eds. Handbook of Organization Studies. Sage, London, UK (pp. 175190).

Van de Ven, A. H. (1986). Central problems in the management of innovation. Management Science, 32(5), 590-607.

Van de Ven, A. H. (2007). Engaged Scholarship: A Guide for Organizational and Social Research. Oxford UK, Oxford University Press.

Van de Ven, A. H. \& Poole, M. S. (1995). Explaining development and change in organizations. Academy of Management Review, 20, 510-540.

Van Dijk, S., Berends, H., Jelinek, M., Romme, A.G. L., \& Weggeman, M. (2011). Microinstitutional affordances and strategies of radical innovation. Organization Studies, 32(11), 1485-1513.

Wijen, F., \& Ansari, S. (2007). Overcoming inaction through collective institutional entrepreneurship: Insights from regime theory. Organization Studies, 28/7, 1079-1100.

Wittneben, B., Okereke, C., Banerjee, B., \& Levy, D. (2009). Climate change and the emergence of new organizational landscapes. Organizational Studies, 30, 1013-1014. 
Wolfson, M. (2011a). Green energy future 'bright,' Windsor conference hears. The Windsor Star, September 6, 2011.

Wolfson, M. (2011b). Liberals, PCs spar over jobs, Hudak called threat to green sector. The Windsor Star, September 9, 2011.

Wolfson, M. (2011c). Green Act changes spark fear. The Windsor Star, November 2, 2011.

Wolfson, M. (2011d). Solar manufacturers take Hydro One to task. The Windsor Star, November $12,2011$.

Wolfson, M. (2011e). Solar future feared to be dimming: LaSalle firm lays off 20 employees. The Windsor Star, November 15, 2011.

Wolfson, M. (2012a). Solar pump, cart spark interest: Local firm builds green exports. The Windsor Star, March 22, 2012.

Wolfson, M. (2012b). Solar biz gets boost. The Windsor Star, June 23, 2012.

Wright, R. (2011). Electric vehicle event in Windsor displays new technology. The Windsor Star, June 3, 2011.

Yin, R.K. (2009). Case Study Research: Design and Methods, $4^{\text {th }}$ Edition. Beverly Hills, CA. Sage.

Zietsma, C., \& Lawrence, T. B. (2010). Institutional work in the transformation of an organizational field: The interplay of boundary work and practice work. Administrative Science Quarterly, 55, 189-221. 
TABLE 1: Interview Participants

\begin{tabular}{|c|c|c|c|}
\hline Organization & Position & 2011 & 2012 \\
\hline Economic Development Corporation & VP Community Development & & $\mathrm{X}$ \\
\hline Environmental Committee for National Union & President & & $\mathrm{X}$ \\
\hline Institutional Renewable Energy Investor & CEO & $\mathrm{X}$ & $\mathrm{X}$ \\
\hline Local Community College & Renewable Energy Program Coordinator & $\mathrm{X}$ & \\
\hline Local Government Workforce Agency & Director of Development & & $\mathrm{X}$ \\
\hline Local Government Workforce Agency & Executive Director & & $\mathrm{X}$ \\
\hline Local Government Workforce Agency & Program Designer & $\mathrm{X}$ & \\
\hline Local Government Workforce Agency & Research and Trend Analyst & & $\mathrm{X}$ \\
\hline Personnel Recruitment Firm & Account Manager for the Energy Sector & $\mathrm{X}$ & \\
\hline $\begin{array}{l}\text { Provincial Government Funding Agency: Green Technology } \\
\text { and Innovation }\end{array}$ & Business Development Manager & & $\mathrm{X}$ \\
\hline Provincial Ministry of Economic Development and Trade & Senior Advisor & $\mathrm{X}$ & $\mathrm{X}$ \\
\hline Provincial Ministry of Energy & Senior Manager, Smart Grid and Network Policy & & $\mathrm{X}$ \\
\hline Renewable Energy Technology Consulting Company & Director of Project Development and Management & & $\mathrm{X}$ \\
\hline Solar Aggregator & Managing Director and Founder & $\mathrm{X}$ & \\
\hline Solar PV Solutions & VP Sales & & $\mathrm{X}$ \\
\hline Solar Panel Manufacturer & General Manager for Canadian Operation & $\mathrm{X}$ & \\
\hline Solar Panel Manufacturer & Founder and CEO & $\mathrm{X}$ & \\
\hline Solar Systems, Engineering and Design & CEO and Founder & $\mathrm{X}$ & $\mathrm{X}$ \\
\hline Solar Technology Installer & CEO and Founder & $\mathrm{X}$ & $\mathrm{X}$ \\
\hline Switchgear Manufacturer & Founder and CEO & $\mathrm{X}$ & \\
\hline
\end{tabular}


FIGURE 1: Organizational Ingenuity in the Ontario Solar Energy Industry, 2009-12

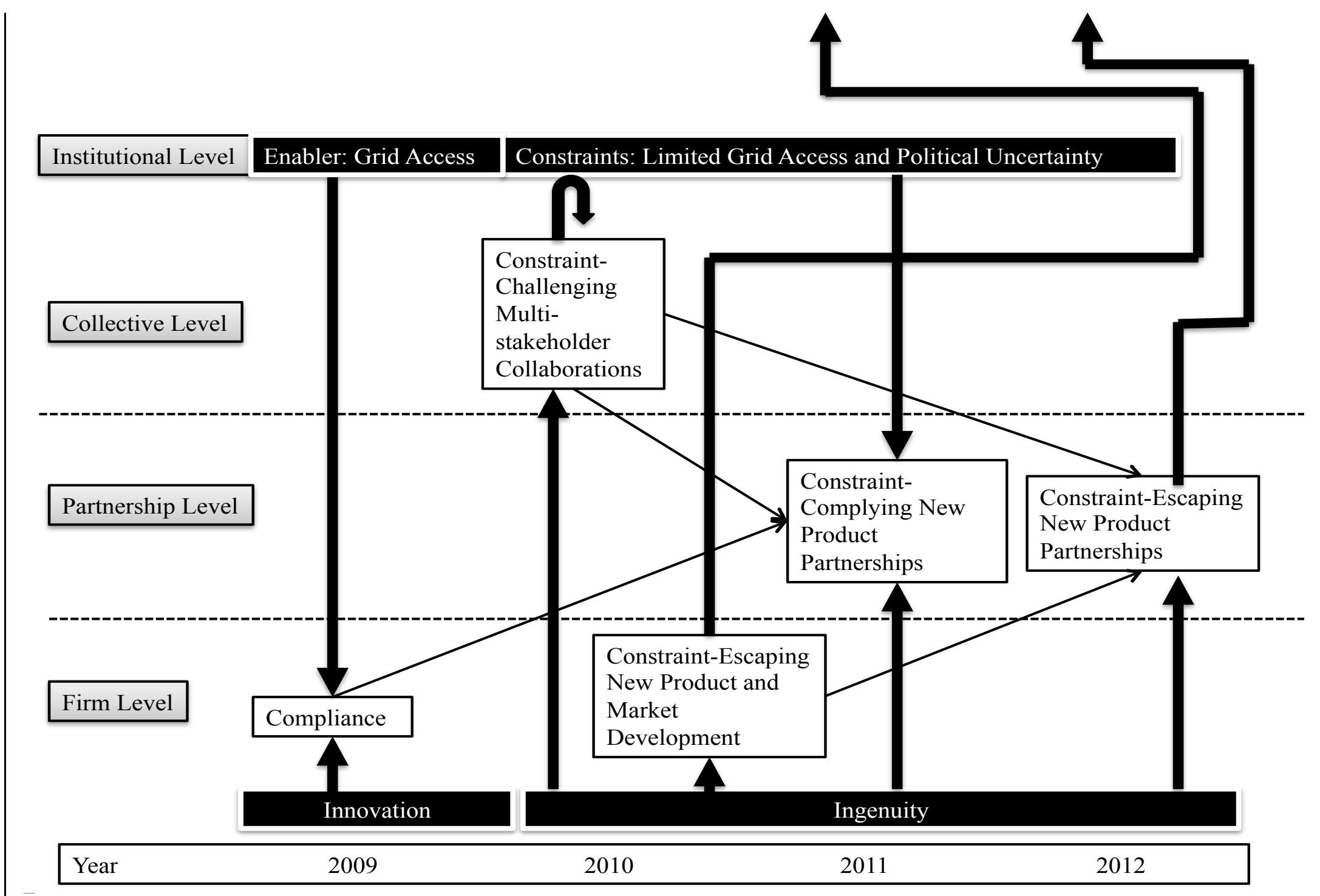

